\title{
Lake and Land Breezes at a Mediterranean Artificial Lake: Observations in Alqueva Reservoir, Portugal
}

\author{
Carolina Purificação ${ }^{1, *}$, Miguel Potes ${ }^{1,2} \mathbb{D}$, Gonçalo Rodrigues ${ }^{1,2} \mathbb{D}$, Rui Salgado ${ }^{1,2} \mathbb{D}$ and Maria João Costa ${ }^{1,2} \mathbb{D}$ \\ 1 Science and Technology School, University of Évora, Rua Romão Ramalho 59, 7000-671 Évora, Portugal; \\ mpotes@uevora.pt (M.P.); grodrigues@uevora.pt (G.R.); rsal@uevora.pt (R.S.); mjcosta@uevora.pt (M.J.C.) \\ 2 Institute of Earth Sciences-ICT, Pole of the University of Évora, Rua Romão Ramalho 59, \\ 7000-671 Évora, Portugal \\ * Correspondence: m40949@alunos.uevora.pt or carolina.purificacao.20@gmail.com
}

Citation: Purificação, C.; Potes, M.; Rodrigues, G.; Salgado, R.; Costa, M.J. Lake and Land Breezes at a Mediterranean Artificial Lake: Observations in Alqueva Reservoir Portugal. Atmosphere 2021, 12, 535. https://doi.org/10.3390/ atmos12050535

Academic Editors: Sukanta Basu and Gunnar W. Schade

Received: 24 February 2021

Accepted: 20 April 2021

Published: 22 April 2021

Publisher's Note: MDPI stays neutral with regard to jurisdictional claims in published maps and institutional affiliations.

Copyright: (c) 2021 by the authors. Licensee MDPI, Basel, Switzerland. This article is an open access article distributed under the terms and conditions of the Creative Commons Attribution (CC BY) license (https:// creativecommons.org/licenses/by/ $4.0 /)$

\begin{abstract}
The Alqueva reservoir, in the Southeast of Portugal, has significantly changed the landscape of the region, with impacts also on the local climate, as documented in this manuscript, namely the thermal circulation in the form of lake and land breezes. Taking advantage of three strategic meteorological stations, two installed at the shores and another on a floating platform located near the center of the reservoir, a detailed analysis of lake and land breeze occurrences during two years is presented in this study. The thermal gradient between the reservoir and the surroundings is the main driver for the breeze development and the meteorological stations placed in opposite sides of the reservoir allow to establish the criteria in order to detect lake and land breezes. The results showed more land breeze than lake breeze occurrences, in line with the more negative thermal gradient between shores and reservoir in the annual cycle. Lake breezes are more frequent in summer months during daytime and land breezes in turn are more frequent in winter months during night-time.
\end{abstract}

Keywords: lake and land breezes; Alqueva reservoir; atmospheric observation; lake-atmosphere interaction

\section{Introduction}

Lake and land breezes are prominent events induced by the thermal contrasts between water and land surfaces, and its structure and magnitude depend on the topography [1,2], the surface area and the seasonality [3]. In particular, lake dimension is a very important point of the study, since the results from Wang et al. [4] indicate that the characteristics of lake and land breezes vary greatly with lake properties, such as lake size and depth. Particularly in regions such as Northern Europe, Asia and North America, the lake surface can be very large and the high density of lakes may affect the regional climate $[5,6]$. Generally, a larger frequency, longer duration, and stronger lake breezes occur more in large and deep lakes than in small or middle-sized lakes [7]. Keen and Lyons [8] found, more than 40 years ago, the existence of lake and land breezes on Lake Michigan that reached until $15 \mathrm{~km}$ away from the study site, while Schoenberger [9], a few years later, discussed land breeze development in wintertime at the same Lake Michigan.

In some regions, the abrupt variation of surface properties can generate organized atmospheric circulation in response to the existence of temperature differences between surfaces, commonly called breezes. The high-water heat capacity in relation to any type of terrestrial soil means that during the day, the solar radiation heats terrestrial surfaces much more intensely than the surface of the reservoir, with reduced variation of the surface water temperature over a daytime cycle [10]. Additionally, topography may contribute to the establishment of breeze circulations, with inversion of the circulation between daytime and night-time situations. During daytime, the surrounding land near a lake acts as a heating source inducing upward motions and allowing a cooler air circulation coming from the water, similar to what occurs in sea breezes. This phenomenon happens when the air 
becomes less dense over land (lower pressure) than over the lake [11]. Consequently, warm air rises over land and cooler humid air descends over the lake creating a depression over land and high pressure over the reservoir, at the surface level. In altitude, the air moves to the lake (where the pressure is lower) and it circulates towards the Earth's surface, closing the circulation [12]. During the night, the opposite circulation can occur, with a current of fresh air taking place from the land to the lake along the slopes. This land breeze is triggered when the surrounding land cools down and the lake surface remains warmer causing the inversion of the circulation, with hot air rising upward in the lake and cooler air descending over the surroundings [13-16].

Observational studies have been used to characterize both the influence and the frequency of the lake and land breezes in several places around the world. Lemmin and Adamo [1] studied the importance of lake-land breezes from analysis of the summer wind components around Lake Geneva, Switzerland in terms of their spatial and temporal characteristics, in particular of lake-land breezes during the period May to September 1981-1987. The duration of individual events between May and October for wind speeds above $5 \mathrm{~ms}^{-1}$ was between 1 and $2 \mathrm{~h}$, and during summer the wind events were shorter and of higher velocity. The authors evidenced that the local topography modifies the lakeland breeze pattern in some parts of the basin and leads in general to spatially variable distributions of wind stress around the lake. Giovannini et al. [17] described that the "Ora del Garda", which is a coupled lake-valley breeze, regularly blows during warm-season clear-sky days in Lake Garda, Italian Alps. The breeze develops on about $70 \%$ of the days in the warmest months, while it rarely occurs from October to February. Moreover, in the warmest months, the "Ora del Garda" reaches the inland weather station on about $80-90 \%$ of the days probably due to the combination of lake and valley effects. Le Moigne et al. [18] studied the Thau lagoon, located in Southern France, which is separated from Mediterranean Sea by a $1 \mathrm{~km}$-wide strip of land. The authors have found sea-breeze events especially focusing on the boundary layer height over the lagoon that rise on average at around 11 UTC and drop in intensity from 18 UTC on, whilst the land breezes were observed on the lagoon from 07 UTC to 08:30 UTC. Nonetheless, sea breeze regimes are usually observed by the end of the afternoon during hot summertime and dry weather conditions [19]. Lake and land breezes may develop over lakes and lagoons located close to the sea, nevertheless these are difficult to distinguish from the sea breezes [20,21].

Tsujimoto and Koike [22] investigated the development mechanisms of lake and land breezes at low latitudes, in Tonle Sap Lake in Cambodia first using in situ observations and satellite images, and after exploring the circulation mechanism through numerical simulations using a mesoscale atmospheric model (Advanced Regional Prediction System, ARPS) that considered cloud formation. Results from the water surface temperature experiment suggest that warm water surface temperature $\left(30.6^{\circ} \mathrm{C}\right)$ served to initiate the updraft, whereas a lower water surface temperature $\left(25.6^{\circ} \mathrm{C}\right)$ could not. Tonle Sap Lake is a very shallow lake, with average and maximum depth of 2 and $10 \mathrm{~m} \mathrm{[23],} \mathrm{thus} \mathrm{easily}$ warmed, hence, these lake characteristics enable the development of strong land breezes with updraft movements.

The Alentejo region, south of Portugal, is influenced by the continental and maritime climate depending on the distance to the coast. In the interior of the Alentejo region, the climate presents humid and cold winters and dry and hot summers [24]. Salgado et al. [25] showed that the low-level summer circulation in Alentejo is forced by land-sea thermal contrasts that give rise to a quasi-permanent thermal low frequently located over the central region of the Iberian Peninsula. In the region, the strong sea breeze can reach more than $100 \mathrm{~km}$ inland, influencing the interior areas of the country in the late afternoon, as shown by the increase in the wind intensity and its rotation [25].

The generation of lake breezes near the Alqueva reservoir has already been the subject of some studies. Lopes et al. [26] studied the effect of the lake breeze in Alqueva reservoir in the local atmospheric electric potential gradient. Potes et al. [27] studied lake-atmosphere interactions at the Alqueva reservoir and found observational evidence of lake breeze by 
comparing the measurements in three stations located at the lake shores: Amieira, Barbosa and Cid Almeida. More recently, Iakunin et al. [16] quantified the lake breeze effects induced by the Alqueva reservoir from simulations with the mesoscale atmospheric model Meso-NH coupled to the FLake freshwater lake model. Two simulations with the presence and absence of the reservoir on the model surface were performed and compared with meteorological data collected during an intensive observational period in summer 2014 . The authors stated that the breeze system starts to form in the morning and the peak of the wind speed reaches $6 \mathrm{~ms}^{-1}$ during the afternoon, while the dissipation stage of the lake breeze system is anticipated with the arrival of the larger-scale sea breeze from the Atlantic coast late in the afternoon. In addition, the simulations indicate that the lake breeze could be detected at a distance of more than $6 \mathrm{~km}$ away from the lake shores.

However, none of the previous studies dealt with land breezes. The present work intends to address thermal circulations in Alqueva reservoir in a global way, including lake and land breezes. Therefore, this is the first study of observational evidence of Land Breezes in the region. This study was performed in the framework of the ALOP (ALentejo: Observation and Forecasting systems, http:/ / www.alop.ict.uevora.pt/?lang=en, accessed on 28 October 2020) project, and the lake and land breeze effects are investigated using data from automatic weather stations located at the shores and at the center of the reservoir during two years [28]. This work is organized as follows: Section 2 gives an overview of the Alqueva reservoir, Lake and Land breeze characterizations at Alqueva and details of the methodology adopted for detection of Breezes between onshore stations at opposite sides; In Section 3, results of two years of breezes are shown as well as stronger lake and land breeze cases during the period of study; conclusions are given in Section 4.

\section{Data and Methodology}

\subsection{Site Description}

The Alqueva reservoir is located along $83 \mathrm{~km}$ of the main course of Guadiana River, in the interior of Alentejo, as shown in Figure 1. Considered one of the largest artificial lakes in Europe, it represents a strategic water reserve for the south of Portugal covering the municipalities of Moura, Portel, Mourão, Reguengos de Monsaraz and Alandroal and occupying an area of $250 \mathrm{~km}^{2}$ with a flood flow of 12,000 $\mathrm{m}^{3} / \mathrm{s}$ [28-30] and maximum depth of $65 \mathrm{~m}$. The reservoir is a large natural laboratory for the study of the interaction between inland water bodies and the atmosphere. This artificial lake, belonging to the Guadiana basin, has significantly modified the landscape of the region and has impacts on the local climate that are still poorly documented [31].
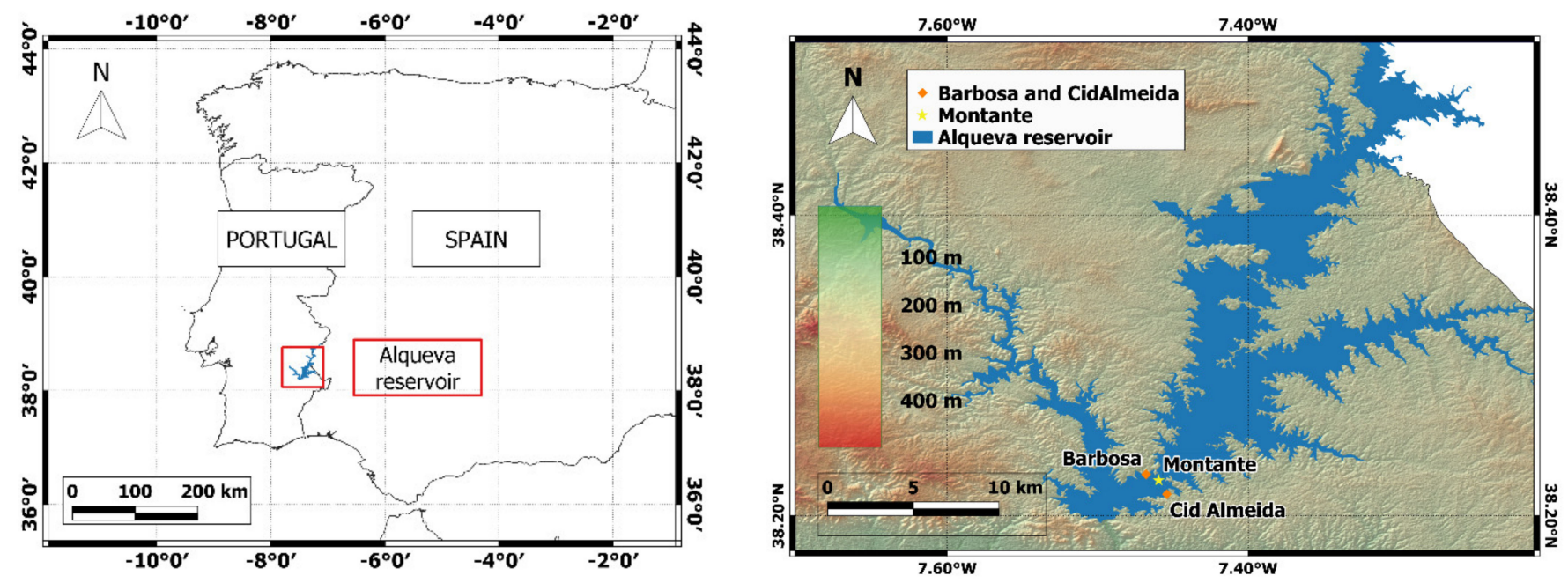

Figure 1. Localization of Alqueva reservoir (left panel) and location of meteorological stations used in this study (right panel). Source: QGIS. 
Previously to the construction of the dam, a case study was carried out on the environmental impact that the influence area of the Alqueva Multipurpose Project (including an irrigation area of around 120,000 ha) would have on the climate. One of the conclusions of the study was that there could be a reduction in the $2 \mathrm{~m}$ air temperature during summer, with a substantial reduction in the maximum temperature (of the order of $-7^{\circ} \mathrm{C}$ ) and also in the daily thermal amplitude (of the order of $-5^{\circ} \mathrm{C}$ ) over densely irrigated areas [32]. However, since the filling phase of the reservoir until the present, only a few studies have been developed on the impact of the lake water body in the local climate.

\subsection{Meteorological Stations at Alqueva Reservoir}

In the framework of the ALOP project, the protocols for collection and storage of the data in the meteorological stations were harmonized in order to guarantee accurate comparison between the observations. This study is based on observations and analysis of meteorological parameters from a set of three automatic weather stations installed in the region in the period comprised between 1 May 2017 and 30 April 2019. The project ALOP takes advantage of the facilities already installed in the reservoir. The meteorological station on the floating platform Montante was installed during the filling phase (2002) by the Portuguese Environment Agency [29]. The onshore stations were installed in the vicinity of the Montante station on opposite shores to support the measurements of the platform and to study the effect of lake and land breeze. The three weather stations are separated by approximately $2 \mathrm{~km}$ (Figure 1): one at the north shore identified as Barbosa $\left(38^{\circ} 13^{\prime} 39.18^{\prime \prime} \mathrm{N}, 7^{\circ} 28^{\prime} 14.74^{\prime \prime} \mathrm{W}\right)$, one at the south shore called Cid Almeida $\left(38^{\circ} 12^{\prime} 59.00^{\prime \prime} \mathrm{N}\right.$, $7^{\circ} 27^{\prime} 16.34^{\prime \prime} \mathrm{W}$ ) and another in the middle of these two, installed in a floating platform over the Alqueva reservoir named Montante $\left(38^{\circ} 13^{\prime} 24.75^{\prime \prime} \mathrm{N}, 7^{\circ} 27^{\prime} 34.18^{\prime \prime} \mathrm{W}\right)$. Throughout the manuscript the time used is UTC. Local winter time is the same as UTC and local summer time is UTC +1 .

Barbosa and Cid Almeida stations include the following measuring instruments:

- Thermo-Hygrometer at $2 \mathrm{~m}$ height (air temperature and relative humidity);

- 2-axis Ultrasonic Anemometer at $3 \mathrm{~m}$ height (wind speed and direction);

- Udometer (precipitation);

- Albedometer (downwelling and upwelling solar irradiance).

In Montante the following equipment is installed:

- Temperature Array of 14 thermistors (water temperatures sensors measured at 0.05, $0.25,0.50,1,2,4,6,8,10,12,15,20,30$, and $60 \mathrm{~m}$ depth);

- Integrated open-path analyzer and sonic anemometer (IRGASON) measuring the following parameters at $1.75 \mathrm{~m}$ from the water surface:

- Air temperature;

- Atmospheric pressure;

- Wind speed and direction;

- Water vapor concentration;

- Carbon dioxide concentration.

- Albedometer (downwelling and upwelling solar irradiance);

The meteorological variables of the three weather stations located in Alqueva (Figure 1) were measured every $5 \mathrm{~s}$ in the dataloggers and the averages/accumulation were recorded every minute.

\subsection{Criteria for Breeze Detection between Onshore Stations at Opposite Sides}

Lake and land breeze generation usually occurs under clear sky conditions, calm or light synoptic wind and considerable temperature differences between land and water surfaces. A few studies have proposed some criteria for breeze detection. Giovannini et al. [17] used a set of six objective criteria based on observations of solar radiation, wind speed and direction at two onshore stations, in order to identify lake-breeze days in lake Garda (Italy). Potes et al. [27] used the following criteria to select days with high probability 
of lake breeze occurrence: daily maximum of the temperature difference between air (in Barbosa station) and water (in Montante) greater than $7^{\circ} \mathrm{C}$; and daily average wind speed lower than $3.5 \mathrm{~m} \mathrm{~s}^{-1}$ at Barbosa station. By applying these criteria, the authors ensure high temperature gradients between the lake and the surroundings and avoid the presence of a strong synoptic circulation or a strong sea breeze, which can mask the local effects. They noticed that the wind changed from the north component to the south component at Barbosa station, which is located on the northern shore of the reservoir, whereas at the same time in Cid Almeida station, located on the southern shore of the reservoir, the wind remained from the north quadrant during the period 9-18 UTC.

This study takes advantage of the position of the meteorological stations installed in the shores in relation to the reservoir. The wind directions that represent lake and land breezes should be divided according to the $225^{\circ}-45^{\circ}$ plane i.e., in the SW-NE axis (Figure 2). We based our criteria mainly on wind divergence and convergence over the lake, for lake and land breeze scenario, respectively, discarding some of the criteria presented above. Nevertheless, some of them will be examined in the results.

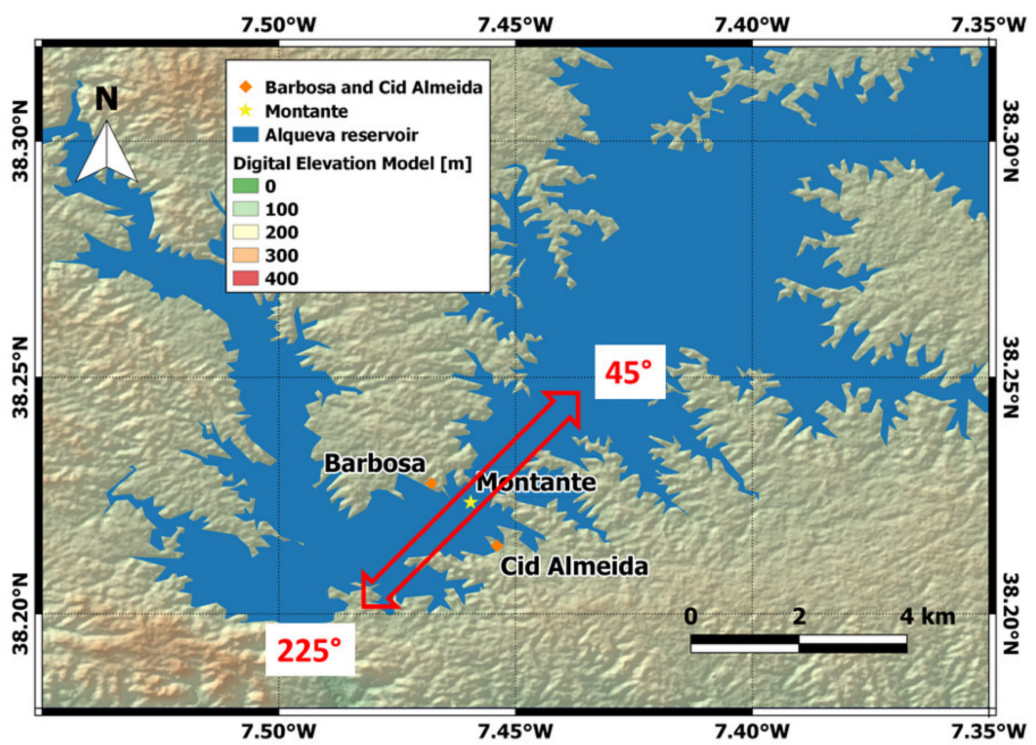

Figure 2. Location of the meteorological stations and the $225^{\circ}-45^{\circ}$ plane (in the SW-NE axis) used in this study to detect the lake and land breeze occurrences. Source: QGIS.

Thus, the following criteria were established:

- For lake breeze scenario, the wind direction on the north shore (Barbosa) had to be greater than $45^{\circ}$ and lower than $225^{\circ}$ (from the lower half-lake side) and at the same time on the south shore (Cid Almeida), the wind should have the opposite direction (from the upper half); we also tested other plans, namely the $240^{\circ}-60^{\circ}$ plane, which is roughly parallel to the southern shoreline of the reservoir, and the results showed only slight differences of the order of $1-3 \%$ of total breeze hours. We decided to apply the $225^{\circ}-45^{\circ}$ plane, which is closest to the reservoir's symmetry axis on this section.

- In case of land breeze circulation, the wind field should be reverse with respect to that of lake breeze case and wind should blow from the upper half (land side) in Barbosa and from the lower half in Cid Almeida;

- Additionally, for both cases the wind direction difference between the two onshore stations has to be greater than $90^{\circ}$ to avoid close directions even in opposite quadrants, that do not represent breeze circulations;

- For both scenarios, daily precipitation events greater than $0.5 \mathrm{~mm}$ were discarded, following Román-Cascón et al. [33];

- Finally, in order to be considered a breeze event at a particular hour, the conditions should be fulfilled during at least twenty minutes. 
With the criteria used in this work, eventual episodes of valley (mountain) breezes may be detected as lake (land) breezes. Given the low relief of the region and with water filling the valley, the anabatic and katabatic winds hardly generate an autonomous breeze system, rather reinforce the lake/land breeze. It is also possible that the flow channeling along the valley (now a reservoir) may generate difluence or confluence of the wind of purely mechanical origin. In this sense and in this work, it is considered that there is a lake breeze whenever the air blows from the lake to the land (simultaneously on both margins) and a land breeze whenever the air blows from land to the reservoir.

\section{Results and Discussion}

\subsection{Thermal Gradient between Lake and Surroundings}

Lake and land breeze events were detected during the two years of study period, between 1 May 2017 and 30 April 2019 at Alqueva reservoir. While lake breeze developed more often in summer and autumn months, land breeze developed along all the year with more occurrences in winter and autumn months. The thermal contrast between the reservoir and adjacent land is the crucial factor for the development of lake and land breezes. In Figure 3 the monthly temperature differences between the onshore stations (Cid Almeida and Barbosa) and the platform station (Montante) are shown. Figure 3a-c shows the monthly differences for average, maximum and minimum air temperatures, respectively, and Figure 3d illustrates the differences between air temperature in onshore stations and water temperature at $0.5 \mathrm{~m}$ depth obtained from the platform station. There are two gaps in the monthly data, in October 2018 and February 2019, due to lack of data in more than 10 days of these months.
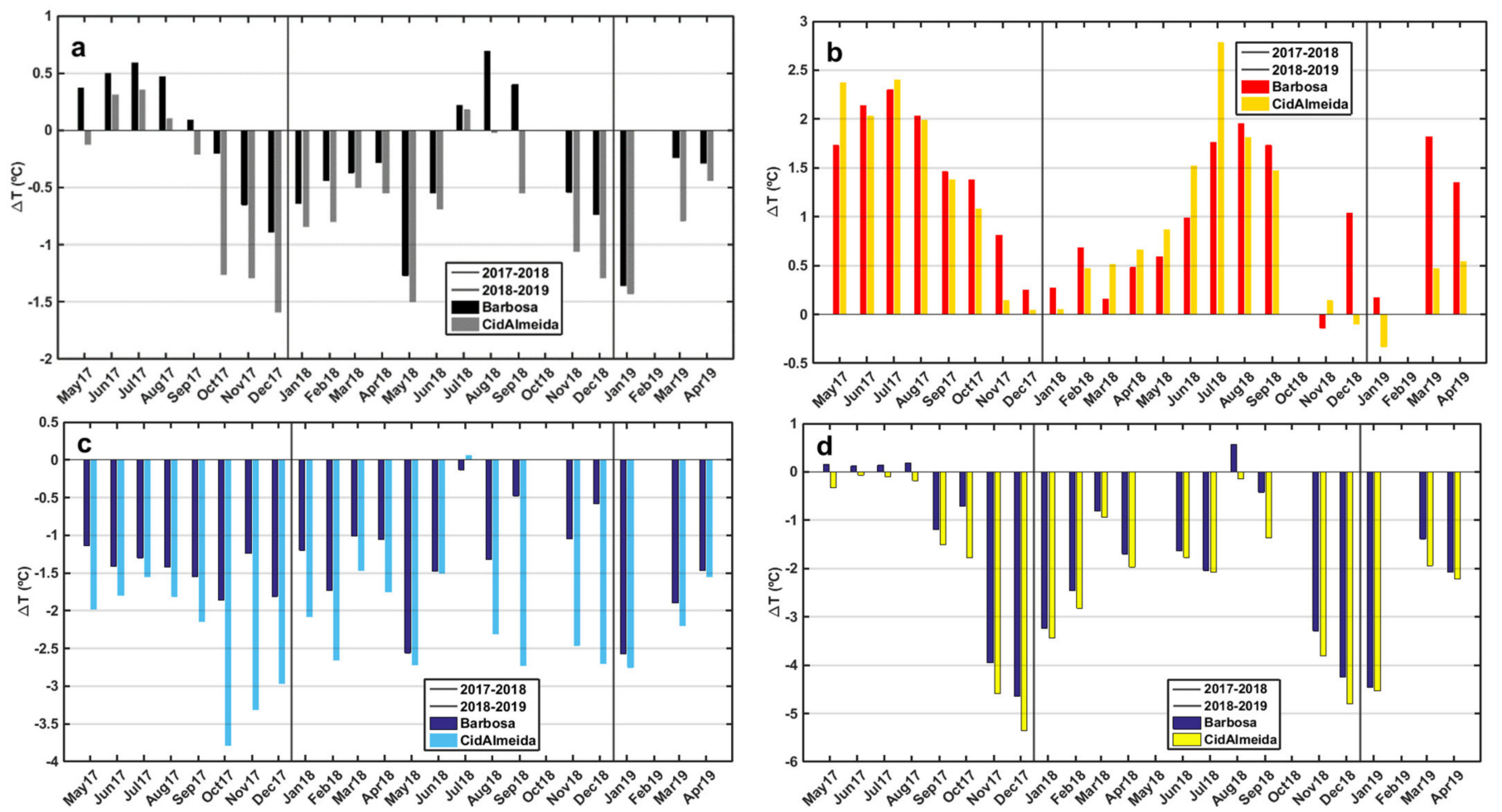

Figure 3. Monthly temperature differences between onshore stations (Barbosa and Cid Almeida) and platform station (Montante) for: (a) mean air temperature; (b) maximum air temperature; (c) minimum air temperature. (d) Monthly difference between air temperature in onshore stations and water temperature at $0.5 \mathrm{~m}$ depth (in Montante station). Grey vertical lines separate the years 2017, 2018 and 2019.

The temperature differences present seasonal dependence showing that in general during summer the average air temperature differences between shores and reservoir are 
positive, while negative differences occur from autumn to spring with more pronounced values in Cid Almeida (Figure 3a). Positive differences mean that lake shores are warmer than the center of the lake, and vice-versa. Between autumn and spring, the air temperature over the lake is higher than at the shores due to higher water surface temperatures with respect to the surrounding land surface, and the opposite is noticed in the summer period. The average air temperature difference was maximum in Cid Almeida in July 2017 with a value of $0.4^{\circ} \mathrm{C}$ and in Barbosa in August 2018 with $0.7^{\circ} \mathrm{C}$. The minimum differences were $-1.6^{\circ} \mathrm{C}$ in December 2017 in Cid Almeida and $-1.4{ }^{\circ} \mathrm{C}$ in Barbosa in January 2019. We note that in May 2017 there was a positive difference in Barbosa and a slightly negative one in Cid Almeida, and in May 2018 both stations present a very negative difference, which can be due to very different meteorological conditions in the springs of these two years. April and May 2017 were drier and warmer than the equivalent months in 2018 that were very humid and colder (Figure 3a,c). For the same reason June 2017 had positive temperature difference and June 2018 had negative difference. Similarly, in September there are some differences between both years. In fact, spring and autumn months represent in the region transition seasons with highly variable conditions in terms of synoptic patterns conditioned by the movement of the polar front, determining the occurrence of Atlantic frontal systems over the area [34].

Regarding the monthly maximum temperature differences, shown in Figure $3 b$, the values are mostly positive throughout the study period with higher values in summer and lower (and slightly negative) during the winter. In Figure $3 c$ the monthly minimum temperature difference is shown. An opposite behavior with respect to that of the maximum difference is noticed with almost all values being negative, presenting lower values in winter. These two plots illustrate the attenuation that the water mass can cause to the air temperature above its surface in relation to the air temperature at both shores, reducing the air temperature amplitude above the reservoir. Water is colder than air and land surface during summer and warmer during the winter.

Figure $3 \mathrm{~d}$ shows the monthly difference between the average air temperature at the onshore stations and the water temperature at $0.5 \mathrm{~m}$ depth in Montante. This plot presents a similar behavior with respect to that shown in Figure 3a, nevertheless, the positive differences in summer are smaller and the negative differences in the rest of the seasons are higher. The different vertical structure of the thermal profile between the summer and the winter explains why, in summer, the lake surface temperature increases during daytime, reducing the thermal contrasts. Contrariwise, the nonstratified profile in winter nights, curbs the decrease of the surface temperature, reinforcing the contrast with the neighboring land. The wind roses for the whole period are presented in Figure 4 for Barbosa and CidAlmeida stations. It is evident the predominance of stronger Northwest winds, with almost 13\% in Barbosa and 10\% in CidAlmeida. In CidAlmeida we also note that more than $8 \%$ of the winds were from the Southeast quadrant.
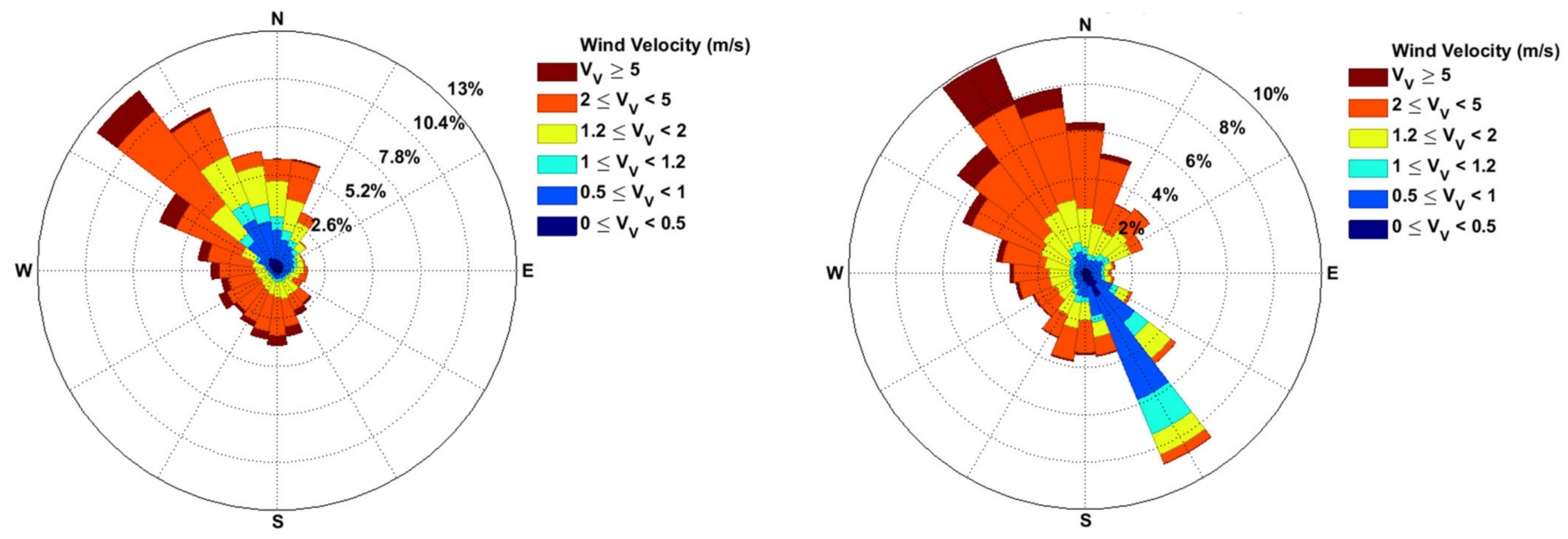

Figure 4. Wind roses for the full period in Barbosa station (left panel) and for CidAlmeida station (right panel). 


\subsection{Lake Breeze}

The number of lake breeze occurrences in hours is shown in Figure 5 at the following scales: monthly (a), daily cycle per month (b) and daily cycle for all period (c). As expected, and according to the positive thermal gradient between the lake and the shores presented in the Section 3.1, the lake breezes are more frequent in summer, spring and autumn and less frequent in winter. There are only a few lake breeze events during night-time with prevalence of daytime events during the study period (Figure 5c). During the entire period (730 days) we found lake breeze in 386 days that more frequently starts at 07:00 and dissipates at 16:00. On average the lake breeze lasts $3.5 \mathrm{~h}$ with maximum duration of $10 \mathrm{~h}$ on 3 August 2018. It can be seen that the maximum number of occurrences happened in August 2018 with a total of 151 h, followed by June, July and August 2017. In August 2018, the highest positive difference between mean air temperature in Barbosa and Montante was registered $\left(0.69^{\circ} \mathrm{C}\right.$-Figure $\left.3 \mathrm{a}\right)$, creating the conditions for lake breeze occurrences. The relationship between the temperature gradient and the strength of the lake breeze was studied. However, the slight tendency found is not statistically significant (not shown here). Most of the lake breeze velocities were between 1 and $2 \mathrm{~m} / \mathrm{s}$ and occurred with temperature gradients between 1 and $3{ }^{\circ} \mathrm{C}$. The breezes occurred in a larger period of the day with maximum incidence between 11:00 and 12:00 (Figure 5b). August 2018 contributes with 19 occurrences at 11:00, to a total of $220 \mathrm{~h}$ that were recorded at 12:00 during all of the study period (Figure 5c). June, July and August 2017 also present positive thermal gradient between onshore stations and platform (Figure 3a) allowing good conditions for lake breeze formation. A total of 112 occurrences were recorded both in June and July while 132 in August 2017.
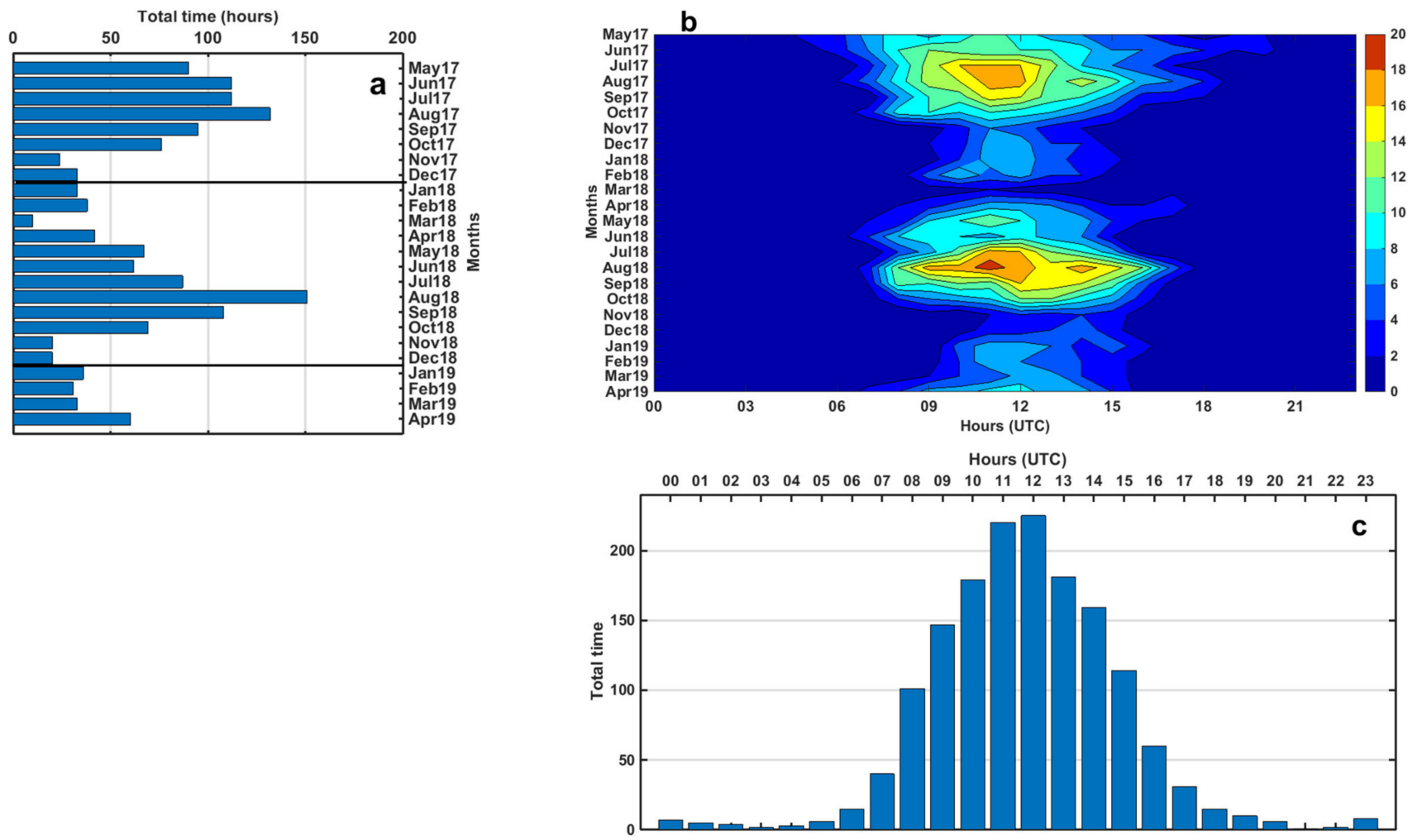

Figure 5. Lake breeze occurrences in hours representing monthly (a), daily cycle per month (b) and daily cycle for the whole period (c). Grey horizontal lines in panel (a) separate the years 2017, 2018 and 2019.

Still, according to Figure 5, the lake breeze occurred most frequently between 07:00 to 16:00. In June and July 2018, the average air temperature was lower than the water temperature at $0.5 \mathrm{~m}$ depth (Figure $3 \mathrm{~d}$ ) by around $2{ }^{\circ} \mathrm{C}$. Thus, it was noticed that these months presented a lower number of lake breeze occurrences than the corresponding 
months of 2017 (Figure 5a). This was due to a very rainy Spring in 2018 (and also February), with monthly accumulated values of precipitation above the climatological normal, e.g., March registered an accumulation of around $200 \mathrm{~mm}$ which is one third of the annual precipitation [35]. This period was very active regarding the passage of frontal systems in Portugal and this synoptic situation, with higher wind speed, inhibited the local thermal circulation. March 2018 presented the minimum number of occurrences, with only $10 \mathrm{~h}$, nevertheless, it was in December 2017 and in January 2019 that the lowest average air temperature differences between Cid Almeida and Montante and Barbosa and Montante occur, respectively. In January 2019, $36 \mathrm{~h}$ of lake breeze were detected, mostly around 11:00 and 12:00. This is due to a period of around 15 days with clear sky, low wind speed and a high thermal amplitude allowing for both lake and land breeze occurrences in the same day.

August 2018 was the month with highest thermal gradient between Barbosa and the middle of the reservoir, as well as highest thermal gradient between air in the Barbosa and the lake water. While in Cid Almeida the highest thermal gradient occurred in July 2017, the second higher for Barbosa was in this month. The highest gradient in August 2018 led to the highest lake breeze occurrences of the whole period, as mentioned before. The daily cycle of the temperature difference between air at the shores and water in Montante for August 2018 is shown in Figure 6. The air temperature in the onshore stations is higher than the water temperature during daytime, coinciding with the period with the highest lake breezes occurrence. During night-time and early morning, the land surface cools and the difference becomes negative, inhibiting the formation of the lake breeze, but allowing the formation of land breezes (discussion in the next section).

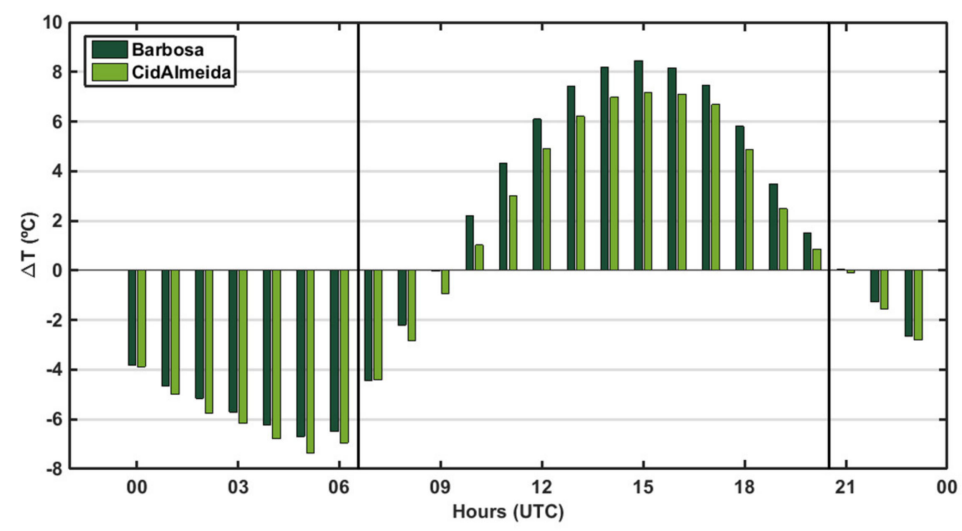

Figure 6. Daily cycle of the temperature difference between air and water at $0.5 \mathrm{~m}$ depth in Montante in August 2018. Grey vertical lines indicate the sunrise and sunset.

\section{Stronger Lake Breeze Cases}

A strong lake breeze case was considered when a day presented more than $6 \mathrm{~h}$ of lake occurrence. During the entire period (730 days) there were 102 days with 6 or more hours of lake breeze. On these days the average wind speed was $1.55 \mathrm{~ms}^{-1}$ with maximum wind speed of $3.65 \mathrm{~ms}^{-1}$ at onshore stations. The average air temperature difference between these stations and the center of the reservoir was $0.9^{\circ} \mathrm{C}$ and between air on the shores and water in the reservoir was $3.55^{\circ} \mathrm{C}$. These particular days presented at the onshore stations an average solar radiation of $600.6 \mathrm{Wm}^{-2}$, relative humidity of $43 \%$ and air temperature of $27.4{ }^{\circ} \mathrm{C}$.

Nonetheless, the day with more lake breeze occurrences was the 3 August 2018, with $10 \mathrm{~h}$. The air temperature for the three stations (upper panel) as well as temperature difference of the onshore stations in relation to the platform (bottom panel) are shown in Figure 7. The air temperature on both shores presents a sharper increase with respect to that over the lake (Montante) and remains higher from 09:00 to 18:00. In the lower panel it is visible that in Barbosa the gradient is up to $8{ }^{\circ} \mathrm{C}$ and in Cid Almeida up to $6{ }^{\circ} \mathrm{C}$, with a 
point value of $7.6^{\circ} \mathrm{C}$ around 13:00, with perfect conditions for lake breeze development. On this day, lake breezes occurred from 07:00 to 10:00, at 12:00, from 14:00 to 17:00 and at 23:00 when the air temperature on the shores suddenly increases and gets higher than that of air above the lake (lower panel of Figure 7).
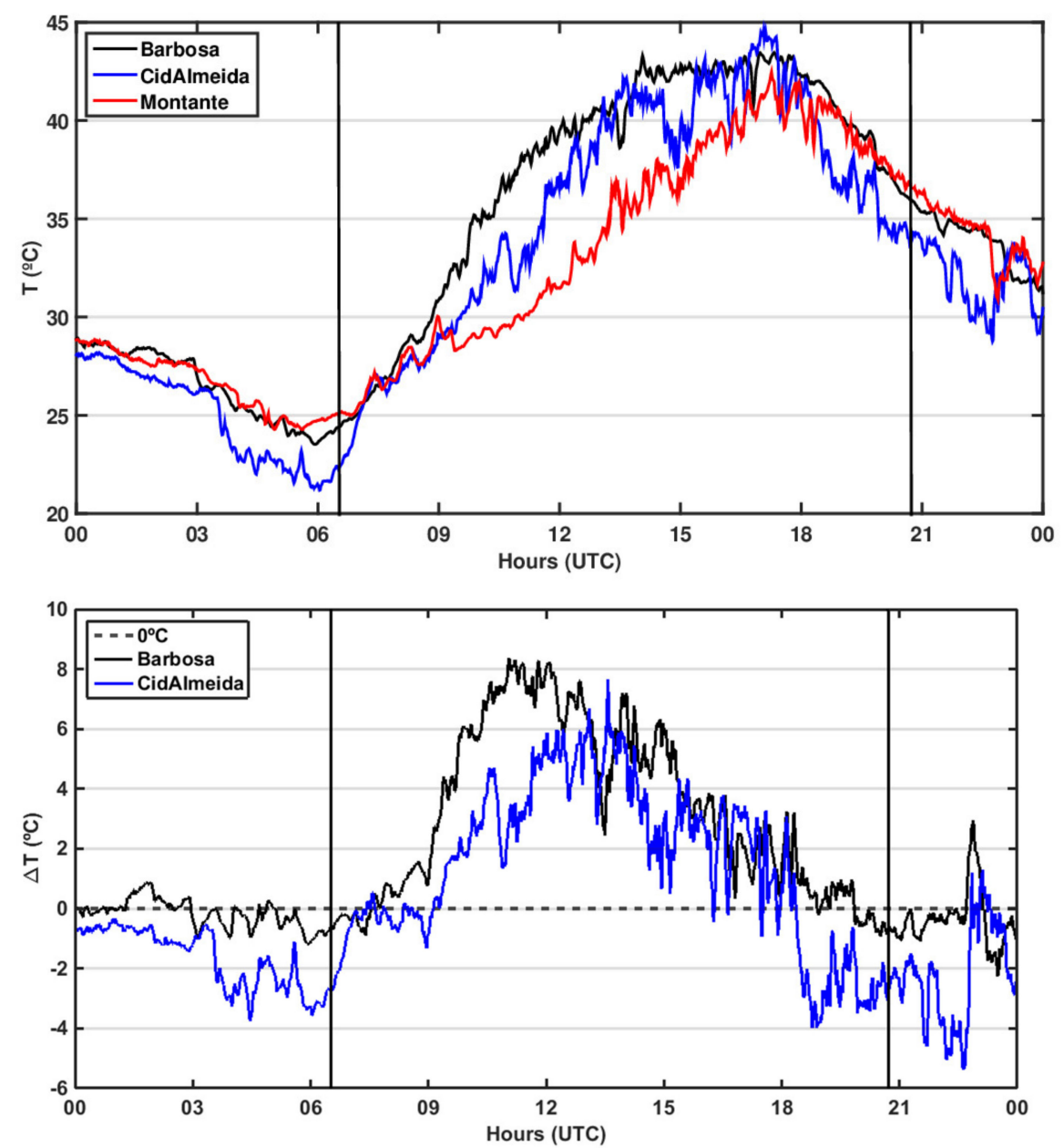

Figure 7. Air temperature in Alqueva (upper panel) and air temperature difference between shores and platform (lower panel) on 3 August 2018. Grey vertical lines indicate the sunrise and sunset.

During 3 August 2018 there was a gradual increase in water vapor concentration in Montante station, reaching $15 \mathrm{~g} / \mathrm{m}^{3}$, as can be seen in Figure 8. This situation lasted until around 11:00, followed by a decrease in water vapor concentration until 18:00 when it starts again to increase. The drop of water vapor in the early afternoon is a signature of the descending branch of the breeze circulation, which causes subsidence of dry air from the upper layers, as described in Iakunin et al. [16]. Finally, water vapor concentration increased again in the late afternoon, with the arrival of moist air associated to the Atlantic sea breeze. The establishment of this larger scale circulation is very common during summer (see Salgado et al. [25] and Iakunin et al. [16]) and overlaps the local wind systems caused by the thermal contrasts between reservoir and land surfaces.

In Figure 9, the wind variation is shown for 3 August 2018. The wind was synoptic from Southwest with maximum intensity between 2 and $3 \mathrm{~m} / \mathrm{s}$ until 03:00, between 03:00 and 07:00 there were situations of land breezes, since there were low wind speeds and opposite quadrant of the wind in Barbosa and Cid Almeida. Lake breezes occurred when the wind blew from the Southernmost quadrant in Barbosa and from the Northernmost in Cid Almeida. As common in summer, the lake breezes tend to be interrupted by the arrival of the Atlantic sea breeze, stronger than the local circulation (see Figure S1 for August 2018 
wind velocity). This phenomenon is visible in Figure 9 from 18:00 to 21:00 when the wind directions of both shores are the same and the wind speed increases. This day present the ideal conditions described by [27], for high probability of lake breeze occurrence: daily temperature difference between air and water greater than $7{ }^{\circ} \mathrm{C}$ and daily average wind speed lower than $3.5 \mathrm{~m} \mathrm{~s}^{-1}$.

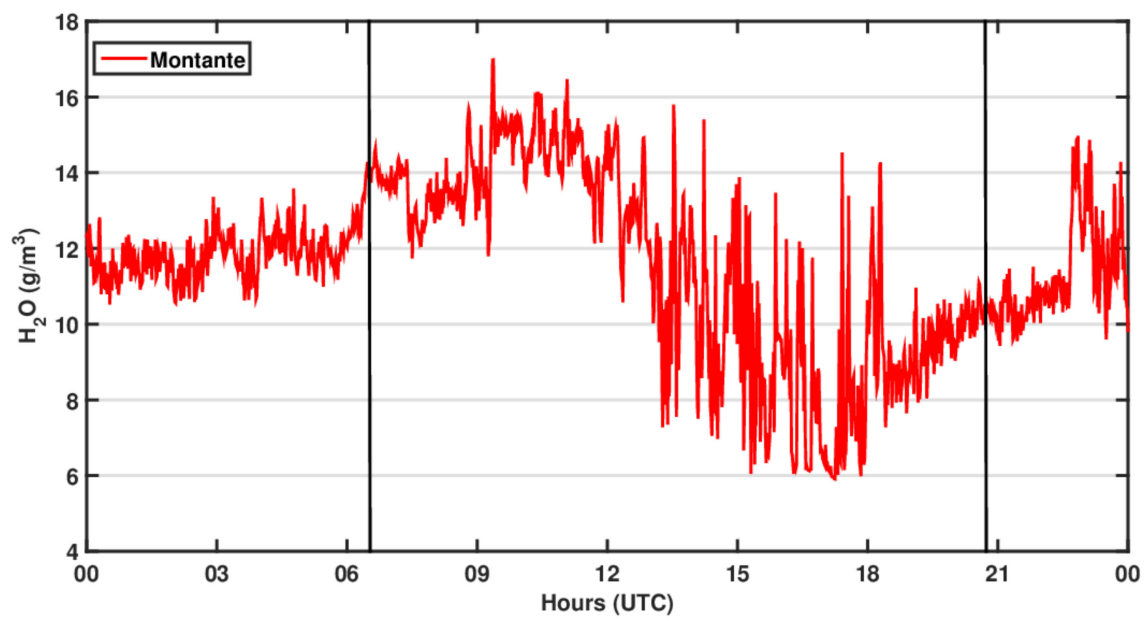

Figure 8. Water vapor in Alqueva (Montante station) on 3 August 2018. Grey vertical lines indicate the sunrise and sunset.
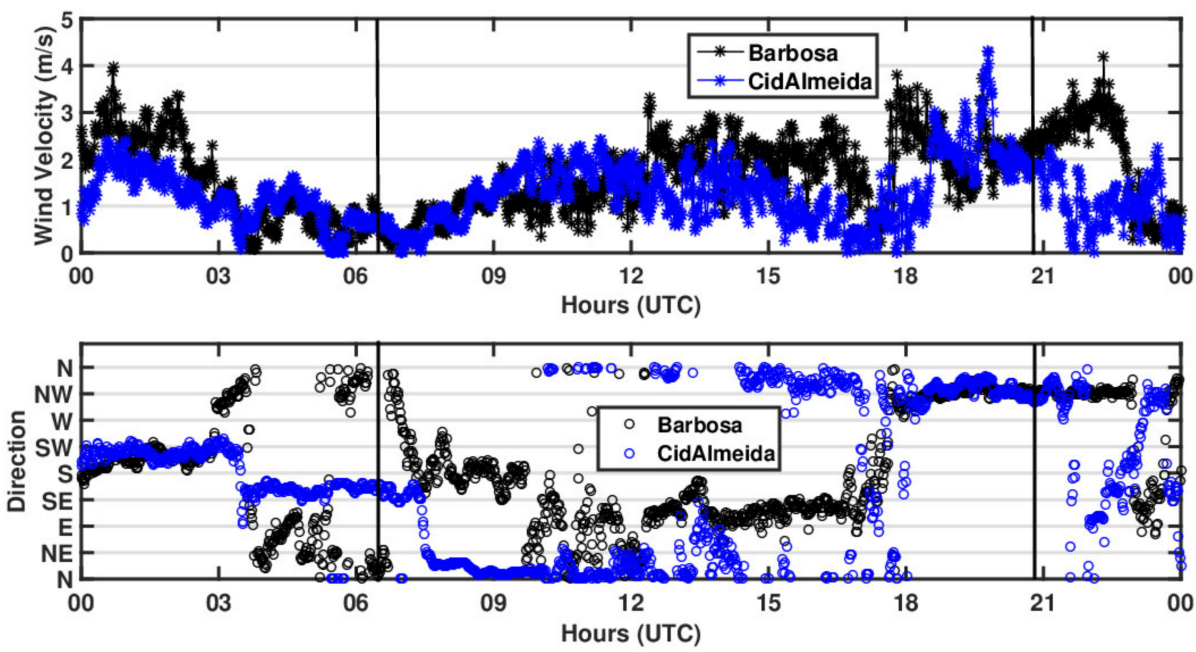

Figure 9. Wind speed (Up panel) and wind direction (Down panel) in Alqueva on 3 August 2018. Grey vertical lines indicate the sunrise and sunset.

To better illustrate the wind field on 3 August 2018, the day with more lake breeze hours $(10 \mathrm{~h}$ ), Figure 10 shows the wind roses, in the upper panel the full day and in the lower panel the lake breeze occurrences. The two upper wind roses show the great variety of directions with light and moderate intensities. However, there were lake breeze occurrence conditions for $10 \mathrm{~h}$ as can be seen in the lower wind roses. There was more variability in directions and speeds in Barbosa (reaching $3.5 \mathrm{~m} / \mathrm{s}$ ) than in Cid Almeida where the directions were more concentrated at just $45^{\circ}$ and did not exceed $2.5 \mathrm{~m} / \mathrm{s}$ (lower panels). 

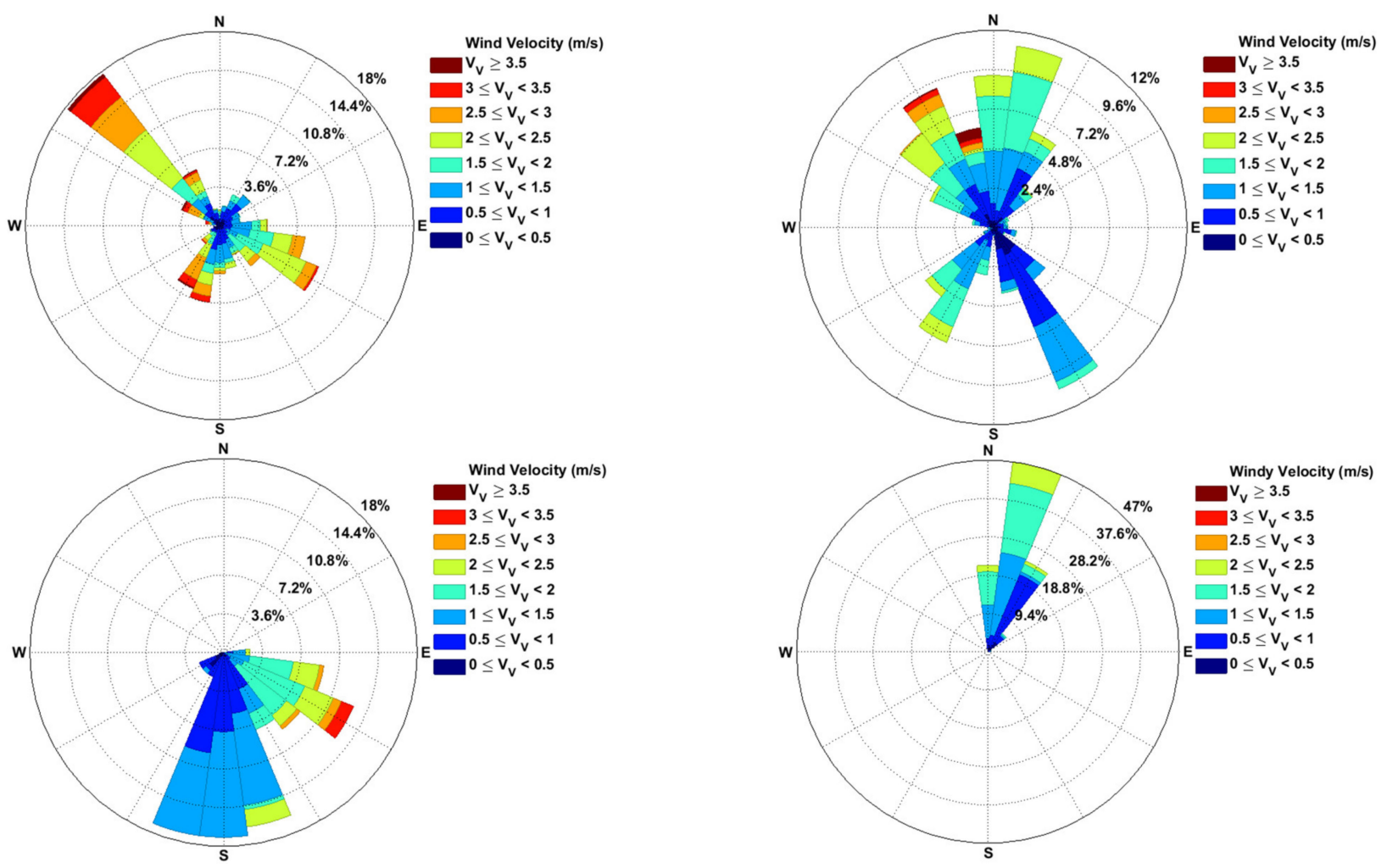

Figure 10. Wind roses for the full day (upper panels) and during land breeze occurrences (lower panels) for Barbosa station in the left panels and for Cid Almeida station in the right panels, on 3 August 2018.

\subsection{Land Breeze}

According to the thermal gradient between lake and shores, presented in Section 3.1, most of the study period presents a negative gradient, with exception for the summer period. Thus, more land breeze than lake breeze occurrences are expected. Figure 11 summarizes the monthly, daily by month and the daily variation of the whole period of land breeze occurrences during the study period. During the entire period (730 days) we found land breeze in 496 days ( $68 \%$ of the days) that normally starts at 17:00 and dissipates at 08:00. On average the land breeze lasts $8.1 \mathrm{~h}$ with a maximum of $17 \mathrm{~h}$ on 1 January 2019. According to Figure 11a, the number of land breeze occurrences per month vary from 28, in July 2018, and 292, in January 2019. Thus, land breeze conditions were twice as frequent as lake breeze conditions. There is also a huge interannual difference between January 2018 and the same month in 2019, which had less than $40 \%$ of land breeze events with respect to January 2019. The air temperature differences between onshore stations and Montante were more negative in 2019 than in 2018 (Figure 3a). The relationship between the temperature gradient and the strength of the land breeze was studied. As noticed for lake breeze case the slight tendency is not statistically significant. Most of the land breeze velocities were between 0.5 and $1.5 \mathrm{~m} / \mathrm{s}$ and occurred with temperature gradients between -6 and $-1{ }^{\circ} \mathrm{C}$. This indicates that land breeze is weaker than lake breeze and develops under greater difference between the shores and the center of the reservoir. As expected, the land breezes occur essentially during night-time when the water temperature is higher than the air temperature. As shown in Figure 11c, the breezes were more frequent between 17:00 and 08:00 with focus in the period comprised between 00:00 and 05:00 (total occurrences greater than 230). The hourly period with more land breeze events was 01:00 with a total of $259 \mathrm{~h}$, which indicates that in about two thirds of the days, a land breeze was identified in the first hour of the day. According to Figure 11b it is noticed that in October 2017 and January 2019, between 21:00 and 05:00 the total land breeze occurrences was maximum, with values greater than 20 occurrences. 

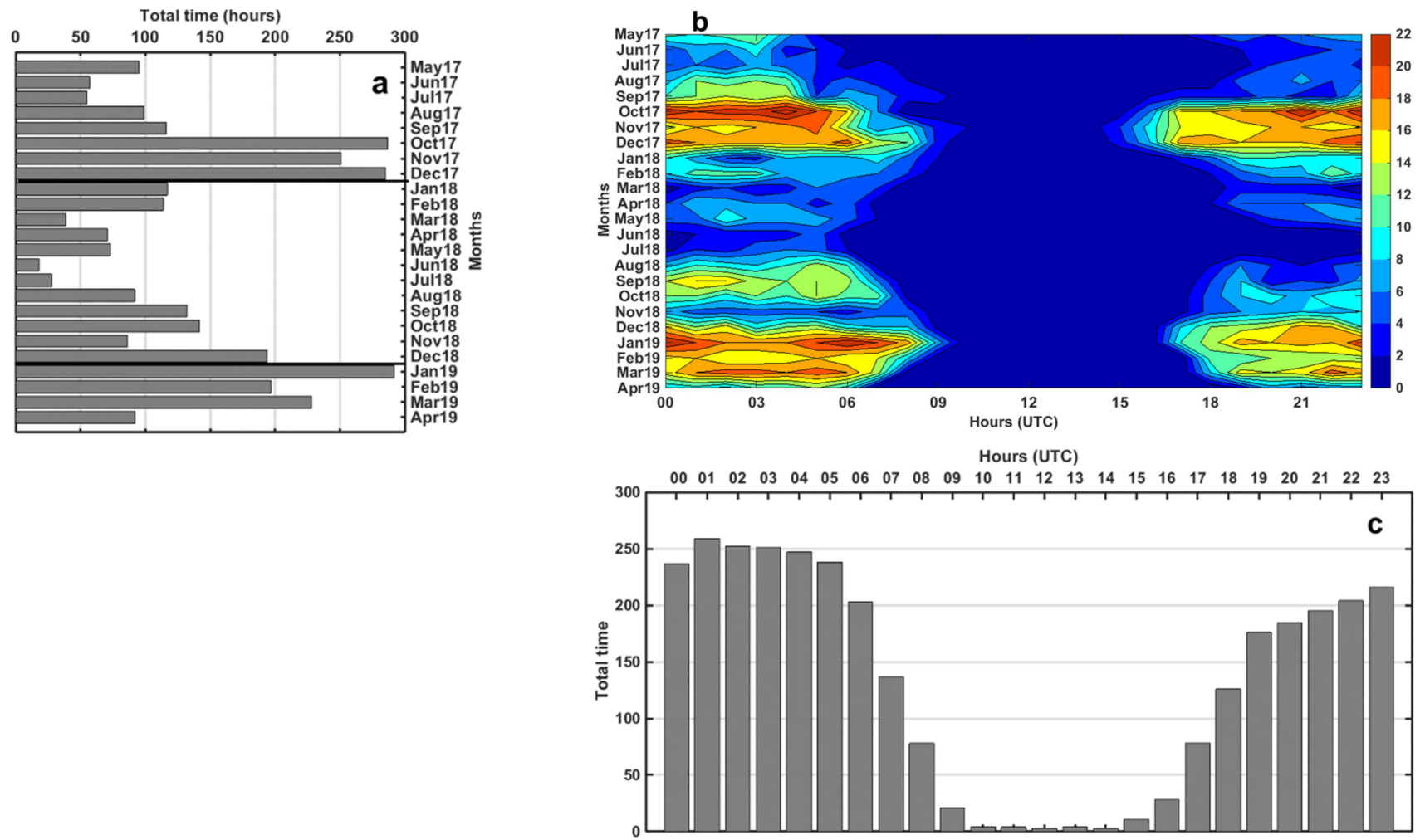

Figure 11. Land breeze occurrences in hours representing monthly (a), daily cycle per month (b) and daily cycle for all period (c). Grey horizontal lines in panel (a) separate the years 2017, 2018 and 2019.

On summer days, the air temperature can be very high, with maximum temperatures close to $40^{\circ} \mathrm{C}$, far above water temperature nevertheless, in the summer months of 2017 and in August 2018, the average temperature of the water is still slightly higher than air in Cid Almeida and slightly lower than air temperature in Barbosa (Figure 3d). This explains that, even in summer, there are frequent conditions for the development of land breezes, for example, land breeze episodes were detected in situations where the air temperature decreases rapidly and water temperature remains warm, causing a negative difference between shores and lake, resulting in a total of $92 \mathrm{~h}$ in August 2018 (151 h of lake breeze in the same month as shown in Figure 5a).

Figure 12 presents the daily cycle difference between the air temperature of the onshore stations and the water temperature in Montante, for January 2019, with 292 occurrences of land breeze. The more negative values occurred from 00:00 to 07:00, which coincides with the periods of more land breezes (Figure 11b), and also with the period with lower wind speeds (Figure S2). The mean difference in the afternoon is slightly positive, which inhibits land breeze formation until 16:00. From 17:00 onwards there are again conditions for land breeze formation.

\section{Stronger Land Breeze Cases}

In order to better describe the stronger land breeze events at Alqueva reservoir a detailed analysis of the days with more than $8 \mathrm{~h}$ was performed. In the entire period (730 days) there were 174 days with 8 or more hours of land breeze. On these days the average wind speed was $0.9 \mathrm{~ms}^{-1}$ with maximum wind speed of $2.5 \mathrm{~ms}^{-1}$ on shore stations. The average air temperature difference between these stations and the center of the reservoir was $-1.9{ }^{\circ} \mathrm{C}$ and between air on the shores and water in the reservoir was $-6.1^{\circ} \mathrm{C}$. These particular days presented at the shore stations an average solar radiation of $24.3 \mathrm{Wm}^{-2}$ denoting mainly nocturnal breeze, relative humidity of $80 \%$ and air temperature of $11.5^{\circ} \mathrm{C}$.

The 1 January 2019, the day with the greatest land breeze duration (in hours) was chosen. Figure 13 shows the evolution of the air temperature in the three stations and the 
temperature difference between shores and platform for that day. A total of $17 \mathrm{~h}$ of land breeze occurrence was registered divided in the periods 00:00 to 09:00 and from 17:00 until the end of the day.

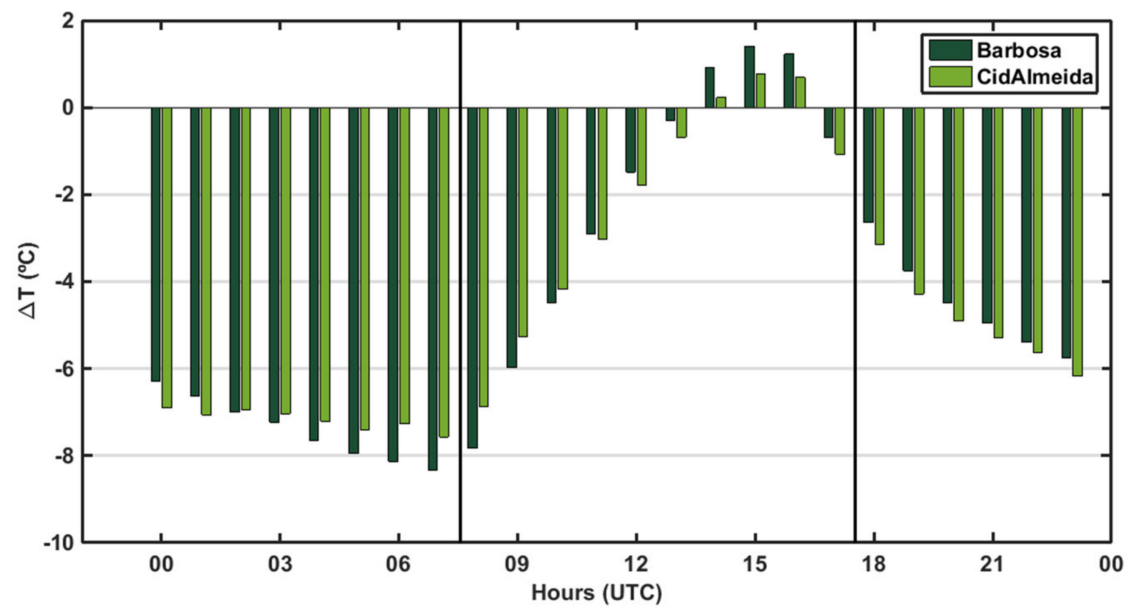

Figure 12. Daily cycle of the temperature difference between air temperature in the shore stations and water temperature at $0.5 \mathrm{~m}$ depth in Montante during January 2019. Grey vertical lines indicate the sunrise and sunset.
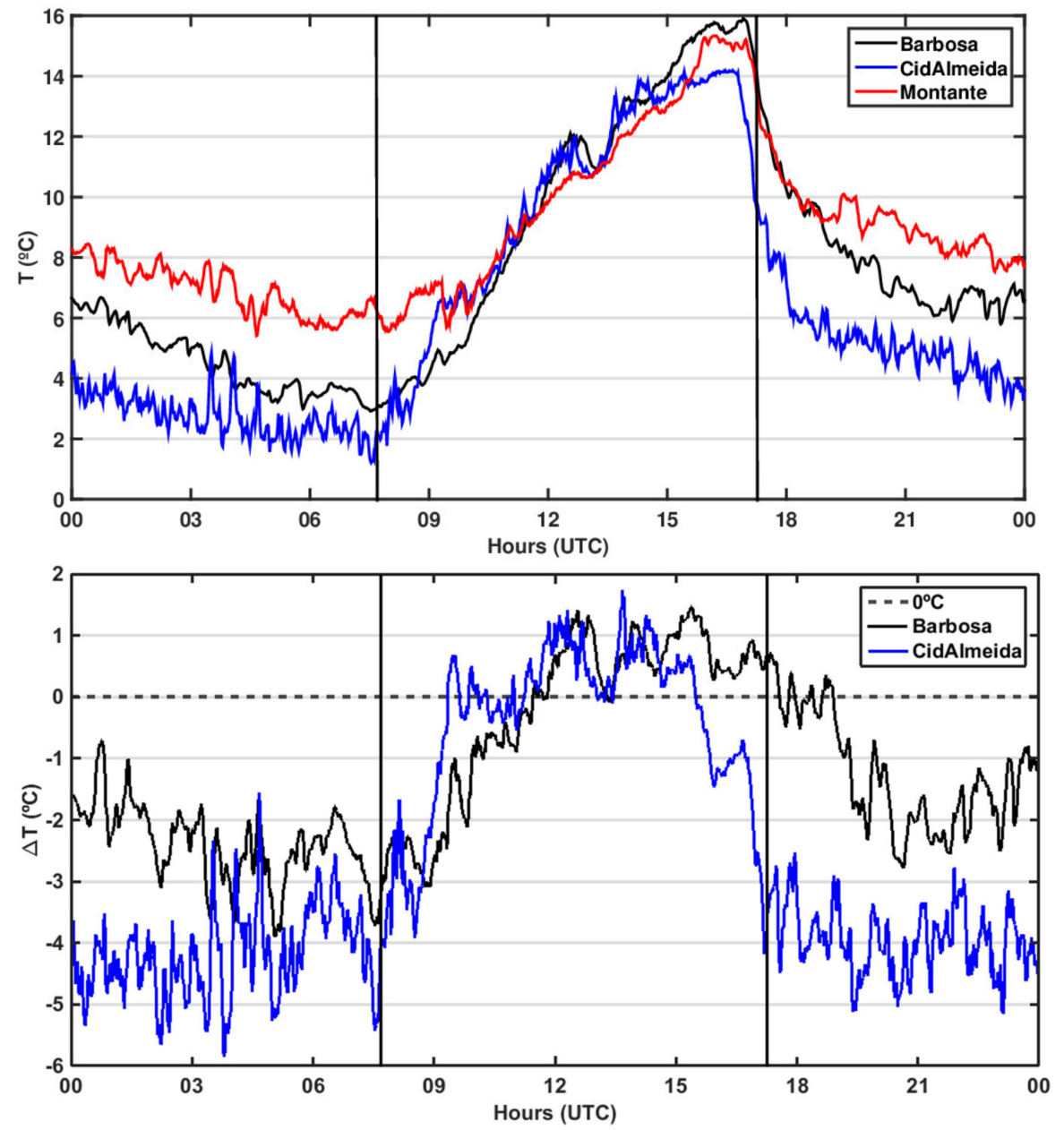

Figure 13. Air temperature in Alqueva (upper panel) and air temperature difference between shores and platform (lower panel) on 1 January 2019. Grey vertical lines indicate the sunrise and sunset. 
During the night and early morning, air temperature in Montante (red line) is higher than the temperature in the onshore stations, with anomalies down to $-5^{\circ} \mathrm{C}$, as can be seen in the lower panel, thus leading to the development of land breezes. During the morning and afternoon, the temperature was very close between the three stations, inhibiting the formation of breezes. From 16:00 onwards the difference became negative again in Cid Almeida while in Barbosa only at 19:00.

The evolution of the wind speed and direction are shown in Figure 14 for the same day. Wind speed does not exceed $3.0 \mathrm{~m} / \mathrm{s}$ at both stations. From 00:00 to 09:00 it is visible in the lower panel of Figure 14 that wind blows from opposite directions on the reservoir shores, from Northern quadrant in Barbosa and from Southeast in Cid Almeida. However, during midday there were periods of coincident directions and a small period around 12:00 when the wind changes direction in the two stations, from Southernmost in Barbosa and Northernmost in Cid Almeida. From 17:00 on the wind direction in Cid Almeida maintains again in Southeast direction while in Barbosa some scatter is present, but mainly from Northern quadrant. In summary, the wind directions are opposite on the lake shores for a large part of the day at low wind speeds, resulting from the land breeze conditions.
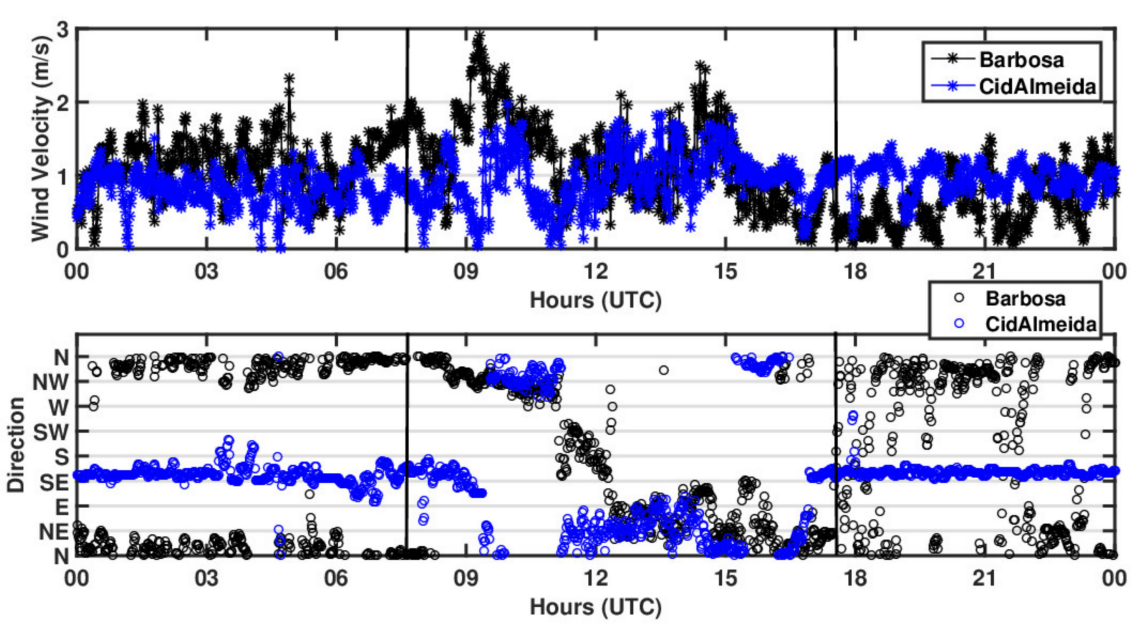

Figure 14. Wind speed (Upper panel) and wind direction (lower panel) in Alqueva on 1 January 2019. Grey vertical lines indicate the sunrise and sunset.

The same data represented in Figure 14 can be seen in Figure 15 for the same day, but in wind rose format. The first two wind roses (top panel) show the full day while the next two (bottom panel) only show the period of land breeze occurrences. The total $17 \mathrm{~h}$, in the lower panel, are clearly marked with opposite wind directions, NNW in Barbosa and SSE in Cid Almeida station. In the upper panel a greater scatter of wind direction is visible in Barbosa, already mentioned above.
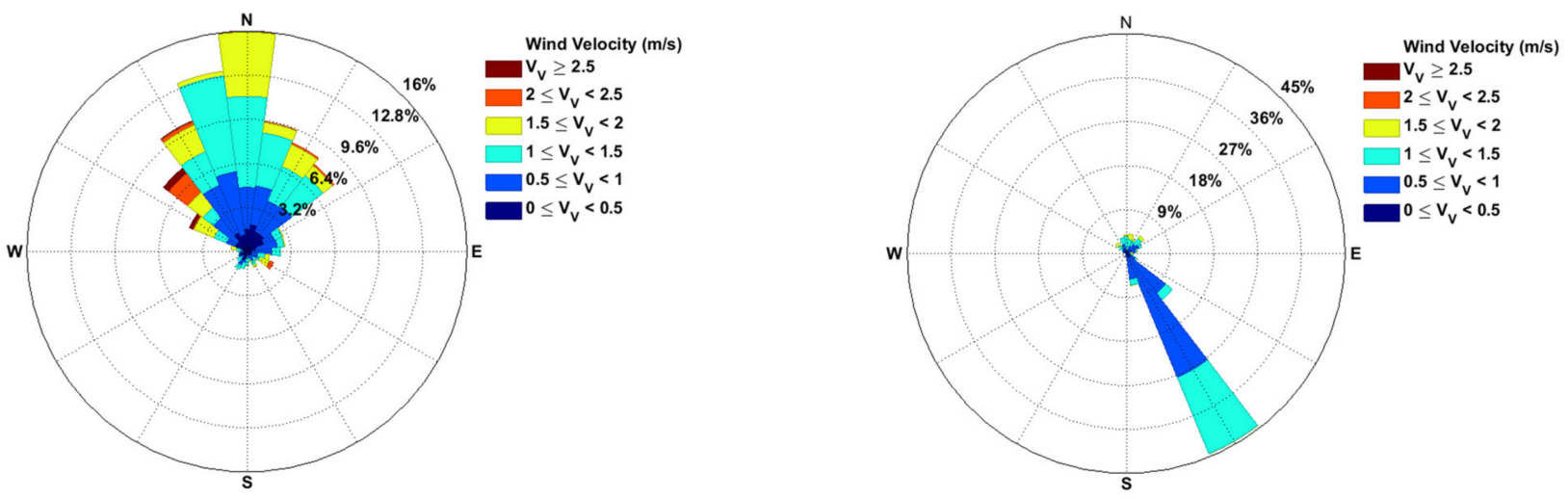

Figure 15. Cont. 

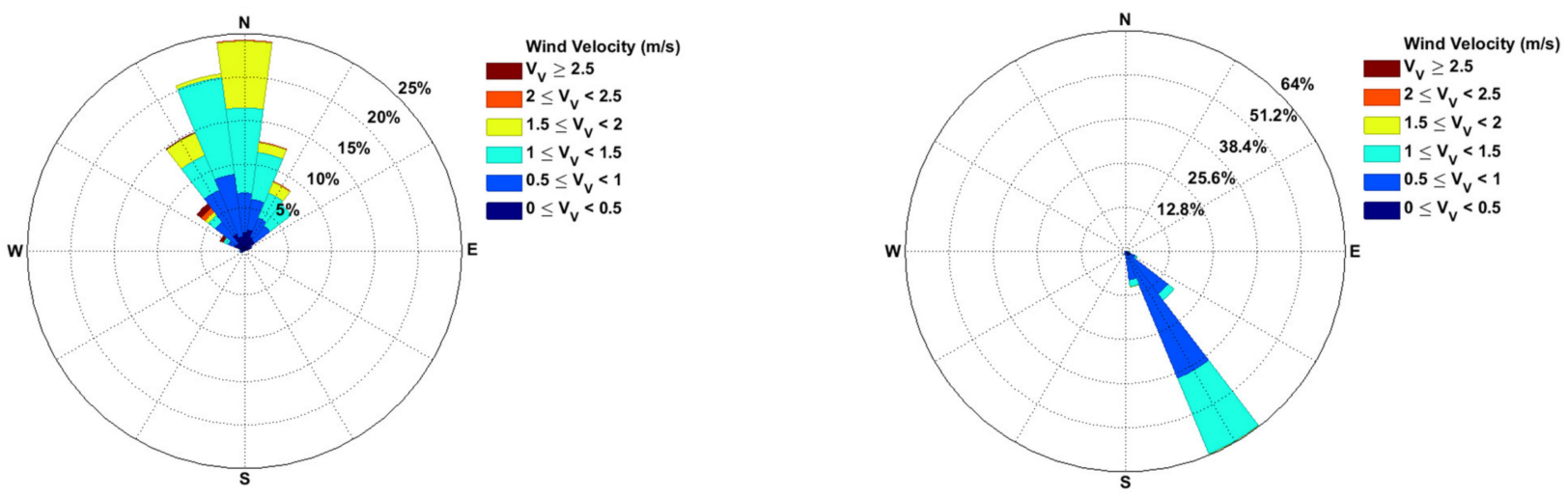

Figure 15. Wind rose for the full day and during land breeze occurrences for Barbosa station in the left panels and for Cid Almeida station in the right panels on 1 January 2019.

\section{Conclusions}

The objective of this study was to explore the lake and land breezes in a large Mediterranean reservoir: the Alqueva reservoir. The study was based on 2 years (May 2017 to April 2019) of in situ atmospheric measurements in three meteorological stations, in the framework of a regional Horizon 2020 project: the ALentejo Observation and Prediction system (ALOP project, [28]).

It was shown that the thermal gradient established between the shores and the center of the reservoir is the main trigger for the development of lake and land breezes, however, low wind speed is also a necessary condition to allow the development of the local circulation, thus excluding moderate and strong synoptic and convective circulation. The thermal gradient analysis was twofold: the air temperature difference between the shores and the center of the reservoir and difference between the air temperature in the shores and the water surface temperature (depth of $0.5 \mathrm{~m}$ ) also in the center of the reservoir. Positive differences drive lake breezes while negative differences drive land breezes and the higher the difference, the greater is the probability to have local breeze development.

A couple of criteria based on wind direction in two meteorological stations installed at opposite shores of the reservoir, distanced about $2 \mathrm{~km}$ from each other, were proposed for lake and land breeze detection and quantification. Simultaneous wind should be from opposite directions in both onshore stations and from lake or land direction depending on the station. These criteria follow the studies of Giovannini et al. [17] and Potes et al. [27]. In this study the temperature difference between the air in Barbosa and the water in Montante in lake breeze scenario was on average $5.5^{\circ} \mathrm{C}$, whereas the threshold from Potes et al. [27] was greater than $7{ }^{\circ} \mathrm{C}$. If these criteria are considered, only $31 \%$ of the occurrences will be detected, thus it can be concluded that the criteria from Potes et al. [27] underestimates the lake breeze. According to the same authors, the threshold for wind speed was lower than $3.5 \mathrm{~ms}^{-1}$ and for this study the average value for the same station is $1.46 \mathrm{~ms}^{-1}$.

During the study period a higher frequency of land breezes was observed with respect to lake breezes, yielding a total of $3160 \mathrm{~h}$ versus $1541 \mathrm{~h}$. This fact is due to the negative thermal gradient between the shores and the center of the reservoir, the lake surface in the middle is warmer than the ground surface in the shores, thus heating more of the air above the water than above the shores. This gradient is positive in summer when the lake breeze occurred more frequently. Lake breeze developed during daytime, more frequently between 07:00 and 16:00, and has no expression during night-time. Nevertheless, in summer the strong Atlantic sea breeze can often reach Alqueva region in the middle/late afternoon with stronger wind fields, suppressing the local circulations. On the contrary, the thermal gradient tends to be negative from autumn to spring and it is in this period that land breezes occur more frequently. The land breeze was also found during night-time when the air above the lake was warmer than the air in the shores, and almost insignificant 
during the day due to radiative heating. Land breezes are more frequent between 17:00 and 08:00.

August 2018 was the month of the study period with the most lake breeze events, with a total of $151 \mathrm{~h}$, and was the month with greater thermal gradient between the shores and the lake. In the case of land breeze, the month with more occurrences was January 2019 with a total of $292 \mathrm{~h}$ and was one of the months with lower negative thermal gradient. On the other hand, also in summer there are conditions for land breeze circulation, and examples of that are the 92 occurrences of land breezes detected in August 2018. Therefore, in some parts of the day, in this month, there were conditions for the development of both lake and land breezes.

Overall, this work documents the formation of thermal circulations, giving rise to lake and land breezes, due to thermal gradients between the shores and the center of an artificial lake. In line with other (few) studies, the results quantify the frequency of occurrence of breezes, showing their importance in the local wind regime. In particular, this study shows a very high frequency of occurrence of land breezes near the borders of a Mediterranean reservoir.

Supplementary Materials: The following are available online at https:/ /www.mdpi.com/article/10 .3390/atmos12050535/s1, Table S1: Number of hours of lake breeze occurrences, Table S2: Number of hours of land breeze occurrences, Figure S1: Daily cycle of the wind velocity in Alqueva in August 2018, Figure S2: Daily cycle of the wind velocity in Alqueva in January 2019.

Author Contributions: The five authors conceptualized the study. C.P., M.P. and G.R. installed the stations, carried out the maintenance and organized the database. R.S. and M.J.C. designed the methodology. C.P. wrote the first draft of the manuscript. All authors contributed to the analysis, interpretation and writing. All authors have read and agreed to the published version of the manuscript.

Funding: The work is cofunded by the European Union through the European Regional Development Fund, included in the COMPETE 2020 (Operational Program Competitiveness and Internationalization) through ALOP project (ALT20-03-0145-FEDER-000004) and by the national funds through FCT—Fundação para a Ciência e Tecnologia, I.P., in the framework of the ICT project with the references UIDB /04683/2020.

Data Availability Statement: Data used in this study are available at http:/ /www.alop.ict.uevora. pt/index.php/dados/?lang=en, accessed on 28 October 2020.

Acknowledgments: The authors gratefully acknowledge the Foundation for Science and Technology (FCT), and the project ALOP (ALT20-03-0145-FEDER-000004).

Conflicts of Interest: The authors declare no conflict of interest.

\section{References}

1. Lemmin, U.; D'Adamo, N. Summertime Winds and Direct Cyclonic Circulation: Observations from Lake Geneva. Ann. Geophys. 1996, 14, 1207-1220. [CrossRef]

2. Gerken, T.; Biermann, T.; Babel, W.; Herzog, M.; Ma, Y.; Foken, T.; Graf, H.-F. A Modelling Investigation into Lake-Breeze Development and Convection Triggering in the Nam Co Lake Basin, Tibetan Plateau. Theor. Appl. Climatol. 2014, 117, 149-167. [CrossRef]

3. Crosman, E.T.; Horel, J.D. Sea and Lake Breezes: A Review of Numerical Studies. Bound. Layer Meteorol. 2010, 137, 1-29. [CrossRef]

4. Wang, Y.; Gao, Y.; Qin, H.; Huang, J.; Liu, C.; Hu, C.; Wang, W.; Liu, S.; Lee, X. Spatiotemporal Characteristics of Lake Breezes over Lake Taihu, China. J. Appl. Meteorol. Climatol. 2017, 58, 2053-2065. [CrossRef]

5. Balsamo, G.; Salgado, R.; Dutra, E.; Boussetta, S.; Stockdale, T.; Potes, M. On the Contribution of Lakes in Predicting Near-Surface Temperature in a Global Weather Forecasting Model. Tellus A Dyn. Meteorol. Oceanogr. 2012, 64, 15829. [CrossRef]

6. Kheyrollah Pour, H.; Duguay, C.; Martynov, A.; Brown, L.C. Simulation of Surface Temperature and Ice Cover of Large Northern Lakes with 1-D Models: A Comparison with MODIS Satellite Data and in Situ Measurements. Tellus A Dyn. Meteorol. Oceanogr. 2012, 64, 17614. [CrossRef]

7. Zhang, X.; Huang, J.; Li, G.; Wang, Y.; Liu, C.; Zhao, K.; Tao, X.; Hu, X.-M.; Lee, X. Improving Lake-Breeze Simulation with WRF Nested LES and Lake Model over a Large Shallow Lake. J. Appl. Meteorol. Climatol. 2019, 58, 1689. [CrossRef] 
8. Keen, C.; Lyons, W. Lake/Land Breeze Circulations on the Western Shore of Lake Michigan. J. Appl. Meteorol. Climatol. 1978, 17, 1843. [CrossRef]

9. Schoenberger, L.M. Doppler Radar Observation of a Land-Breeze Cold Front. Mon. Weather Rev. 1984, 112, 2455-2464. [CrossRef]

10. Stull, R.B. An Introduction to Boundary Layer Meteorology, 2nd ed.; Kluwer Academic Publishers: Dordrecht, The Netherlands, 1988; pp. 587-595.

11. Mariani, Z.; Dehghan, A.; Joe, P.; Sills, D. Observations of Lake-Breeze Events during the Toronto 20155 Pan-American Games. Bound. Layer Meteorol. 2018, 166, 113-135. [CrossRef]

12. Sills, D.; Brook, J.; Levy, I.; Makar, P.; Zhang, J.; Taylor, P. Lake Breezes in the Southern Great Lakes Region and Their Influence during BAQS-Met 2007. Atmos. Chem. Phys. 2011, 11, 7955-7973. [CrossRef]

13. Miranda, P.B. Meteorologia e Ambiente; Universidade Aberta: Lisbon, Portugal, 2001; Volume 219.

14. Nogueira, M. Estudo de Brisas e Depressões Térmicas: Aplicação à Península Ibérica. Master's Thesis, University of Lisbon, Lisbon, Portugal, 2009.

15. Assunção, S. Impacto da Introdução da Albufeira de Alqueva no Modelo de Previsão AROME. Master's Thesis, University of Évora, Évora, Portugal, 2017.

16. Iakunin, M.; Salgado, R.; Potes, M. Breeze Effects at a Large Artificial Lake: Summer Case Study. Hydrol. Earth Syst. Sci. 2018, 22, 5191-5210. [CrossRef]

17. Giovannini, L.; Laiti, L.; Zardi, D.; Franceschi, M. Climatological Characteristics of the Ora del Garda Wind in the Alps. Int. J. Climatol. 2015, 35, 4103-4115. [CrossRef]

18. Le Moigne, P.; Legain, D.; Lagarde, F.; Potes, M.; Tzanos, D.; Moulin, E.; Barrié, J.; Salgado, R.; Messiaen, G.; Fiandrino, A.; et al. Evaluation of the Lake Model FLake over a Coastal Lagoon during the THAUMEX Field Campaign. Tellus A Dyn. Meteorol. Oceanogr. 2013, 65, 20951. [CrossRef]

19. Bouin, M.-N.; Caniaux, G.; Traullé, O.; Legain, D.; Le Moigne, P. Long-Term Heat Exchanges over a Mediterranean Lagoon. J. Geophys. Res. Atmos. 2012, 117, D23104. [CrossRef]

20. Crosman, E.T.; Horel, J.D. Idealized Large-Eddy Simulations of Sea and Lake Breezes: Sensitivity to Lake Diameter, Heat Flux and Stability. Bound. Layer Meteorol. 2012, 144, 309-328. [CrossRef]

21. Wang, C.-C.; Kirshbaum, D.; Sills, D. Convection Initiation Aided by Lake-Breeze Convergence over the Niagara Peninsula. Mon. Weather Rev. 2019, 197, 3955. [CrossRef]

22. Tsujimoto, K.; Koike, T. Land-lake Breezes at Low Latitudes: The Case of Tonle Sap Lake in Cambodia. J. Geophys. Res. Atmos. 2013, 118, 6970-6980. [CrossRef]

23. Kathleen, M.T.; Christopher, A.D.; Kenneth, P.C.; Kenneth, R.W.; John, W.L., III; Melody, L.H.; Joy, L.H.; Charles, D.S.; Scot, A.S. Southeast Asia-A Climatological Study; Air Force Combat Climatology Center (AFCCC), Scott Air Force Base: San Luis, IL, USA, 1997.

24. Purificação, A.C. Caracterização Meteorológica em Alqueva: Tratamento e Análise de dados. Master's Thesis, University of Évora, Évora, Portugal, 2020.

25. Salgado, R.; Miranda, P.M.A.; Lacarrère, P.; Noilhan, J. Boundary Layer Development and Summer Circulation in Southern Portugal. Tethys 2015, 12. [CrossRef]

26. Lopes, F.; Silva, H.G.; Salgado, R.; Potes, M.; Nicoll, K.A.; Harrison, R.G. Atmospheric Electrical Field Measurements Near a Fresh Water Reservoir and the Formation of the Lake Breeze. Tellus A Dyn. Meteorol. Oceanogr. 2016, 68, 31592. [CrossRef]

27. Potes, M.; Salgado, R.; Costa, M.J.; Morais, M.; Bortoli, D.; Kostadinov, I.; Mammarella, I. Lake-Atmosphere Interactions at Alqueva Reservoir: A Case Study in the Summer of 2014. Tellus A Dyn. Meteorol. Oceanogr. 2017, 69, 1272787. [CrossRef]

28. Salgado, R.; Morais, M.; Palma, P.; Potes, M.; Penha, A.; Novais, M.H.; Antunes, C.; Aranha, S.; Bárias, S.; Barrenho, J.; et al. The ALOP Alentejo Observation and Prediction System Database. Available online: http://www.alop.ict.uevora.pt/index.php/ dados/?lang=en (accessed on 2 February 2019).

29. APA: Barragens de Portugal: Barragem de Alqueva. Available online: http://cnpgb.apambiente.pt/gr_barragens/gbportugal/ FICHAS / Alquevaficha.htm (accessed on 28 October 2020).

30. EDIA, S. A Território: Empresa de Desenvolvimento e Infra-estruturas do Alqueva, S.A. Available online: https://www.edia.pt/ pt/o-que-e-o-alqueva/oterritorio/103/ (accessed on 29 October 2020).

31. Purificação, A.C. (University of Évora); Potes, M. (University of Évora); Salgado, R. (University of Évora). Observação Termométrica em Alqueva entre 2017-2018. 2019. Available online: https://www.researchgate.net/publication/340830536 Observacao_Termometrica_em_Alqueva_entre_2017_e_2018 (accessed on 22 April 2021).

32. Miranda, P.; Abreu, F.; Salgado, R. (ICAT, Faculdade de Ciências, Universidade de Lisboa, Lisboa, Portugal). Estudo de Impacte Ambiental de Alqueva. 1995. Available online: https:/ / core.ac.uk/download/pdf/62475212.pdf (accessed on 22 April 2021).

33. Román-Cascón, C.; Yagüe, C.; Steeneveld, G.J.; Morales, G.; Arrillaga, J.A.; Sastre, M.; Maqueda, G. Radiation and Cloud-Base Lowering Fog Events: Observational Analysis and Evaluation of Wrf and Harmonie. Atmos. Res. 2019, 229, 190-207. [CrossRef]

34. Salgueiro, V.; Costa, M.J.; Silva, A.M.; Bortoli, D. Variability of the Daily-Mean Shortwave Cloud Radiative Forcing at the Surface at a Midlatitude Site in Southwestern Europe. J. Clim. 2014, 27, 7769-7780. [CrossRef]

35. IPMA: Ficha Climatológica 1971-2000 da estação de Évora [557]. Available online: http:/ /www.ipma.pt/bin/file.data/climatenormal/cn_71-00_EVORA.pdf (accessed on 11 February 2021). 